\title{
REMOVAL OF HEAVY METALS FROM AN INDUSTRIAL EFFLUENT BY SYNTHESIZED ZEOLITE: CASE OF BOUNOURA INDUSTRIAL ZONE
}

\author{
Bahaz Hanane1, Hadj Seyd Abdelkader ${ }^{1,2}$, Moulai Kromia3 ${ }^{3}$ Aggoune Mohamed \\ Salah $^{1}$ \\ ${ }^{1}$ Laboratoire de mathematiques et sciences appliquées Université de Ghardaia BP 455 \\ Ghardaia-Algeria \\ ${ }^{2}$ Faculté des Hydrocarbures Université KASDI MERBAH Ouargla BP 511 Ouargla- \\ Algérie \\ ${ }^{3}$ Faculté des Sciences et Technologies Université de Ghardaia BP 455 Ghardaia- \\ Algeria
}

(Recieved December 2019 - Accepted April 2020)

\begin{abstract}
Bahaz, H., Hadj Seyd, A., Moulai, K., \& Aggoun, M. S. (2020). Removal of heavy metals from an industrial effluent by synthesized zeolite: Case of Bounoura industrial zone. Lebanese Science Journal, 21(1), 80-94.

The aim of this paper is the synthesis of a Faujasite type zeolite: $9 \mathrm{SiO}_{2}: \mathrm{Al}_{2} \mathrm{O}_{3}: 3 \mathrm{Na}_{2} \mathrm{O}$ : $12 \mathrm{OH}_{2} \mathrm{O}$ and study its ability to remove heavy metals from an industrial effluent. Characterization of the zeolite was carried out by X-ray diffraction analysis (XRD), Fourier transform infrared spectroscopy (FTIR) and scanning electron microscopy (SEM). The study of the elimination of ten heavy metals on an aqueous effluent, taken from the industrial zone of Bounoua (Algeria), shows that the synthesized zeolite is able to eliminate nearly $40 \%$ of the analyzed heavy metals. the results demonstrate a removal rates of metals in a descreasing order, as following: $\mathrm{Cd}>\mathrm{Mn}>\mathrm{Sn}>\mathrm{Fe}>\mathrm{Cr}>\mathrm{Ni}>\mathrm{Pb}>\mathrm{Mg}>\mathrm{Zn}>\mathrm{Cu}$. Cadmium is the most adsorbed metal with a rate of $86.47 \%$ and copper takes the last position with a removal rate of $19.27 \%$. The kinetics and isotherms study of adsorbtion of cadmium by zeolite shows that the adsorption is managed by kinetics of the pseudo-second order and the Langmuir isotherm represents better the adsorption of this metal. The study demonstrates that, besides the economy, zeolite facilitates the process of adsorbtion. Moreover, the zeolite is very efficient and reliable material to eliminate the heavy metals and to mitigate the problems of pollution of the environment caused by the industrial activities.
\end{abstract}

Keywords: heavy metals, pollution, industrial effluent, isotherms, zeolite Na-Y.

\section{INTRODUCTION}

Industrial activities are almost entirely responsible for environmental pollution, since they generate large quantities of toxic discharges in different solid, liquid and even gaseous forms. These releases present an imminent risk to human health and the environment, as long as they are characterized by a cumulative toxicity. 
Despite standards and guidelines developed to reduce the risks of polluting discharges and laws that penalize offending industrial operators, this scourge continues to increase and industrial pollution continues to accumulate in the environment in many countries around the world.

Heavy metals are among the most abundant pollutants in liquid industrial effluents; these compounds have high potential of toxicity and are highly dangerous to ecosystems and human health. Most of these heavy metals are present in polluted waters including $\mathrm{Hg}, \mathrm{Pb}, \mathrm{Ag}$, $\mathrm{Cu}, \mathrm{Cd}, \mathrm{Cr}, \mathrm{Zn}, \mathrm{Ni}, \mathrm{Co}$ and $\mathrm{Mn}$ (Bhuiyan et al., 2011), and it has been found that many heavy metal ions produce strong health problems and damage plants and animals (Nahar et al., 2018; Dietler et al., 2019). The dangers of pollution of some heavy metals may be acute due to their severe toxicity even at low concentrations (Christensen et al., 2000; Jarup, 2003).

The term "heavy metals" denotes the group of metals and metalloids which engenders soil and water contamination and toxicity. They are associated with elements with a density greater than $5 \mathrm{~g} / \mathrm{cm}^{3}$ and an atomic number greater than 20 (International Union of Pure and Applied Chemistry [IUPAC], 2002). The term heavy metals also refers to elements that are mainly present in trace amounts in the environment, such as copper, chromium, nickel, lead, zinc and cadmium. By virtue of their cumulative nature, even at low rates of concentrations, heavy metals inflict considerable harm on the organism and the environment. There are different sources for heavy metals in the environment (Ying et al., 2019). These sources can be both of natural or anthropogenic origin (Hou et al., 2017). Heavy metals are mainly introduced into groundwater by agricultural and industrial activities, land filling, mining, and transportation (Brad, 2005); and can be easily transferred to human body because they are mediated by water, air, and food (Arshid et al., 2019).

Soil and water contamination by heavy metals and metalloids has been a major concern to human health and environmental quality.

Remediation of these noxious elements has been widely investigated and multifarious technologies have been practiced for many decades (Yanyan et al., 2018), these technologies include chemical precipitation, coagulation, ion exchange, electro coagulation, nanofiltration and electrochemical oxidation (Meenakshi, 2006). However those methods have limitations in terms of high operational and maintenance cost, and generation of waste (Wang et al., 2010). The adsorptive removal of heavy metals has been considered one of the most facile, costeffective, and eco-friendly techniques among the various removal technologies (Mohd et al., 2019; Asad et al., 2019).

Adsorption has attracted much attention from researchers. Adsorption defines the property of certain materials to be fixed to their surface of molecules (gases, metal ions, organic molecules... etc.) extracted from the liquid or gaseous phase in which they are immersed. The fixing on the solid surface is done in a more or less reversible way. Adsorption processes are used for several main applications, such as refining treatments for drinking water, tertiary treatment of wastewater or industrial water (Yadav et al., 2019).

With regard to the industrial effluent treatment, the most employed adsorbents are: activated carbon; mineral adsorbents in form of alumina and various metal oxides; and organic adsorbents in the form of macromolecular resins with large specific surface area. 
Zeolites are remarkable silico-aluminous minerals that have shown their effectiveness in wastewater and industrial discharges treatment; treatment of complex leachates with heavy metals, and gaseous effluents, this is due to their ability to adsorb selectively ions and polarized molecules. Zeolites are characterized by a large surface area which makes them a good absorbent. Furthermore, they are environmentally safe, eco-friendly, and low cost. Zeolites have high cation exchange capacity and are considered to be an effective material for the removal of heavy metals and very largely used in the treatment of industrial effluents (Merrikhpour et al., 2013).

In this work a Na-Y zeolite has been synthesized successfully by hydrothermal technique. In order to test the adsorbent capacity of this synthesized zeolite, tests for removal of heavy metals contained in an effluent from the largest industrial area of Bounoura of the wilaya of Ghardaïa (Algeria). The initial heavy metals concentrations (in the raw effluent) and final (after treatment) were measured and the yields were determined. Kinetics and adsorption isotherms of cadmium in contaminated solutions with this metal have also been studied.

\section{MATERIAL AND METHODS}

\section{Presentation of the study area}

The Wilaya of Ghardaïa is located in the northern part of the Sahara, $632 \mathrm{~km}$ from the capital Algiers. Ghardaiia is a World Heritage Site (Medejerab, 2009) and is considered a major tourist site in Algeria. The number of inhabitants is 363,598 (2008 statistics). The Wilaya's climate is a desert type dominated by heat, drought and large diurnal and annual temperature differences (Benoudj et al., 2014).

In addition to its tourist importance, the Wilaya of Ghardaïa also has an important commercial and industrial fabric; the two important industrial areas are the cities of Grara and Bounoura.

Bounoura is an industrial zone located on National Road number 1 (NR1), at geographical point $32^{\circ} 26^{\prime} 8^{\prime \prime} \mathrm{N}, 3^{\circ} 42^{\prime} 16^{\prime \prime} \mathrm{E}$ (Figure 1). Its surface area is 118 hectares and includes very important private and state industrial units such as "ALFAPIPE Company" which is a big pipeline manufacturing Company. Another important company is the company of hydrocarbon processing and distribution "NAFTAL unit". Numerous plaster manufacturing and processing units are situated, in this industrial zone. There are also factories for the manufacture of radiators and exhaust pipes, and also factories for the manufacture of copper and luxury valves, as well as units for the manufacture of electrical components. 


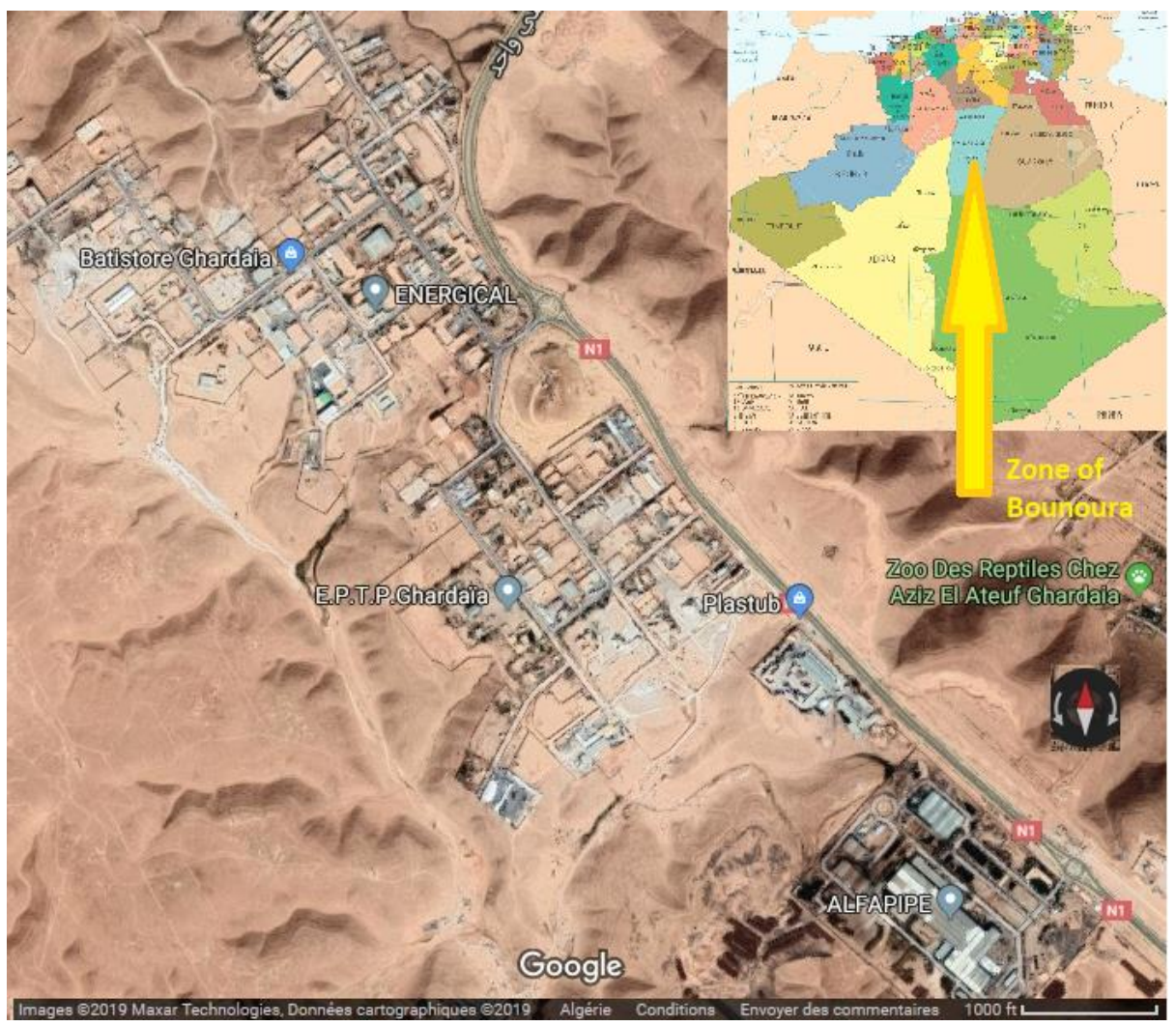

Figure 1. Satellite view of Bounoura industrial zone (Google $\underline{\mathbf{n}, \mathbf{d}})$.

Bounoura area generates a large amount of wastewater in the form of liquid effluents laden with pollutants of various nature, from industrial units. Table 1, below, includes the average physicochemical characteristics of the effluent leaving the area analyzed at the main collector, for the year 2019.

Table 1. Physicochemical characteristics of the effluent leaving the industrial zone.

\begin{tabular}{|l|l|l|l|l|l|l|l|}
\hline Parameter & $\begin{array}{l}\text { Temperature } \\
\left({ }^{\circ} \mathbf{C}\right)\end{array}$ & pH & $\begin{array}{l}\text { Flow } \\
\left(\mathbf{m}^{3} / \mathrm{Day}\right)\end{array}$ & $\begin{array}{l}\text { SM } \\
(\mathrm{mg} / \mathrm{L})\end{array}$ & $\begin{array}{l}\text { BOD5 } \\
(\mathrm{mg} / \mathrm{L})\end{array}$ & $\begin{array}{l}\text { COD } \\
(\mathbf{m g} / \mathrm{L})\end{array}$ & $\begin{array}{l}\text { Conductivity } \\
(\mathbf{m S} / \mathbf{c m})\end{array}$ \\
\hline Value & 17.5 & 5.7 & 25000 & 135 & 128 & 146 & 3.62 \\
\hline
\end{tabular}

\section{Experimental procedure}

\section{Synthesis and characterization of the zeolite}

The synthesis of zeolite is carried out in four steps, shown in Figure 2 below. The reactor used is a stainless steel autoclave, with a polyethylene tetra fluoride (PTFE) of $40 \mathrm{~mL}$ volume. The first step consists to prepare the hydrogel by adding distilled water, $\mathrm{NaOH}$ soda, and a silicon source (LUDOX 25\%). In the second step, curing consists in maintaining the hydrogel under strong agitation, during a period of a few ten minutes at several hours at room temperature (Nik et al., 2007; Majid, 2015).Curing allows homogenizing the reaction mixture. In the third step, the hydrogel obtained after stirring is transferred to a PTFE-coated steel reactor under autogenous pressure at a temperature of $80^{\circ} \mathrm{C}$ for 3 days (Holmberg et al., 2003; Aderemi, 
2004). In the last step, the zeolite is finally recovered, after crystallization, separated by filtration, washed with distilled water with a vacuum pump, and dried at $50^{\circ} \mathrm{C}$ for one night.

Characterization of the zeolite was carried out by X-ray diffraction analysis using a Bruker MeasSrv diffractometer, Fourier transform infrared spectroscopy (BRUKERFT-IR) and scanning electron microscopy.

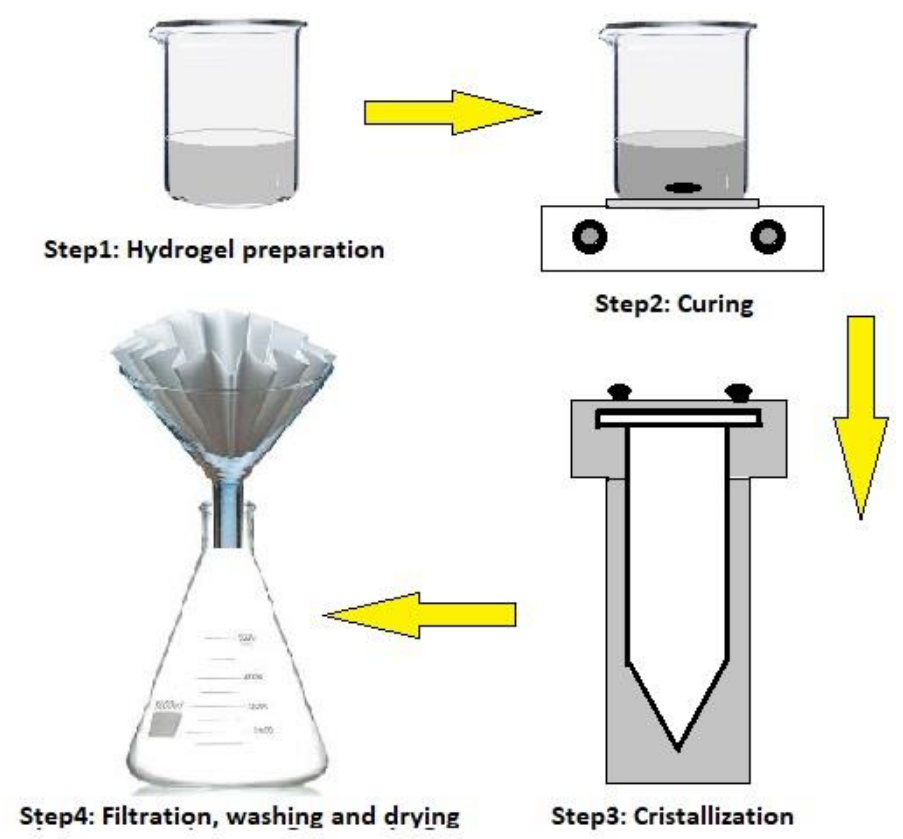

Figure 2. Zeolite synthesis steps.

\section{Adsorption assay}

Samples of the liquid industrial effluent were collected at different time intervals from the main effluent collector located at the outlet of the Bounoura industrial zone. The samples were taken during the month of March 2019, mixed and analyzed by three repetitions; the average was taken into account. The computation of the concentration of pollutants is accomplished by the standard techniques recommended by the American Public Health Association (American Public Health Association [APHA], 1998) and Algerian standards. Physicochemical parameters such as $\mathrm{pH}$ and temperature were taken on site using a multiparameter analyzer (HORIBA-U 22). All other analyzes were carried out at the Mathematics and Applied Sciences Laboratory of Ghardaïa University (Algeria).

In order to study the removal performance of heavy metals by the synthesized zeolite, $500 \mathrm{~mL}$ of raw wastewater was shacked for one hour in $0.5 \mathrm{~g}$ of zeolite, at constant temperature $\left(25^{\circ} \mathrm{C}\right)$. After agitation and filtration employing Whatman 42 filter paper, the filtrate was analysed in order to determine the concentration of heavy metals by atomic absorption spectrometry (AAS). The heavy metal removal efficiency were calculated using the formula (1) below (Shamsan et al., 2018):

$$
\text { Removal rate }(\%)=\frac{C_{i}-C_{f}}{C_{i}} \times 100
$$


With:

$\mathrm{C}_{\mathrm{i}}$ : initial concentration of the metal in $\mathrm{mg} / \mathrm{L}$ at the raw effluent.

$\mathrm{C}_{\mathrm{f}}$ : final concentration of the metal in $\mathrm{mg} / \mathrm{L}$ in the treated effluent.

\section{Kinetic study}

One characteristic with overarching importance that defines the absorption efficiency is the absorption kinetics. In this work, cadmium was chosen to study adsorption kinetics. $\mathrm{Cd}\left(\mathrm{SO}_{4}\right)$, $8 \mathrm{H}_{2} \mathrm{O}$ (Merck analytical products) was used as a source for Cd (II) ions, then a stock solution $(1 \mathrm{~g} / \mathrm{L})$ was prepared from the obtained concentrated solution. The working solutions were prepared by means of dilution of stock solution. A series of adsorption essay, for different initial concentrations of $\mathrm{Cd}(\mathrm{II})$, ranging from 25 to $100 \mathrm{mg} / \mathrm{L}$, by measuring in each the adsorbed quantity $\mathrm{Q}_{\mathrm{t}}$ at time $\mathrm{t}(\mathrm{t}=30,60,90,120$ and $150 \mathrm{~min})$ and to carry $\log \left(\mathrm{Q}_{\mathrm{e}}-\mathrm{Q}_{\mathrm{t}}\right)$ and $\mathrm{t} / \mathrm{Q}_{\mathrm{t}} \mathrm{in}$ function of time, kinetics of the pseudo first order and pseudo 2nd order are represented by the following models in equations (2) and (3), respectively (Elwakeel et al. 2017):

$$
\begin{aligned}
& \ln \left(\mathrm{Q}_{e}-\mathrm{Q}_{t}\right)=\operatorname{Ln}\left(\mathrm{Q}_{e}\right)-\mathrm{K}_{1} \cdot \mathrm{t} \\
& \frac{\mathbf{t}}{\mathbf{Q}_{t}}=\frac{\mathbf{1}}{\mathbf{K}_{\mathbf{2}} \mathbf{Q}_{e}^{2}}+\frac{\mathbf{t}}{\mathbf{Q}_{e}}
\end{aligned}
$$

$\mathrm{K}_{1}$ and $\mathrm{K}_{2}$ are, respectively, the first and second order rate constants.

$\mathrm{V}$ : volume of the solution and $\mathrm{m}$ mass of the adsorbent (zeolite). $\mathrm{Q}_{\mathrm{e}}$ and $\mathrm{Q}_{\mathrm{t}}$ are, respectively, the adsorbed amount of $\mathrm{Cd}$ at equilibrium and at time $\mathrm{t}$. These entities are given by the following expressions:

$$
\begin{aligned}
& \mathrm{Q}_{e}(\mathrm{mg} / \mathrm{g})=\frac{\mathrm{C}_{0}-\mathrm{C}_{\mathrm{e}}}{\mathrm{m}} \cdot \mathrm{V} \\
& \mathrm{Q}_{t}(\mathrm{mg} / \mathrm{g})=\frac{\mathrm{C}_{0}-\mathrm{C}_{\mathrm{t}}}{\mathrm{m}} \cdot \mathrm{V}
\end{aligned}
$$

\section{Adsorption isotherms}

Adsorption isotherms relate the equilibrium mass of adsorbed material in the adsorbate phase $\left(\mathrm{Q}_{\mathrm{e}}\right)$ to its equilibrium concentration in the solution phase $\mathrm{C}_{\mathrm{e}}$. Langmuir and Freundlich isotherms of absorption were used to fit the data in the experimentation.

Langmuir's isotherm hypothesizes that the absorption is of monolayer type on a uniform surface, provided that the sites of absorption are of a finite number. Once a site is filled, no further sorption can occur place at that site (Hardiljeet et al., 2011)

The Langmuir equation can be written in the following linear form:

$$
\frac{C_{e}}{Q_{e}}=\frac{1}{Q_{m} \cdot K_{L}}+\frac{C_{e}}{Q_{m}}
$$


Where:

$\mathrm{C}_{\mathrm{e}}$ denotes the concentration of adsorbate at equilibrium (mg. $\left.\mathrm{g}^{-1}\right)$.

$\mathrm{Q}_{\mathrm{m}}$ is the maximum adsorption capacity $\left(\mathrm{mg} . \mathrm{g}^{-1}\right)$.

$\mathrm{K}_{\mathrm{L}}$ is Langmuir constant which refers to adsorption capacity $\left(\mathrm{mg} . \mathrm{g}^{-1}\right.$ ), which can be correlated with the variation of the suitable area and porosity of the adsorbent.

In contrast to Langmuir's isotherm, the isotherm of Freundlich may represent monolayer absorption (chemisorption) and multilayer absorption referred to as physisorption. The assumption of which this model is based on the assumption that the adsorbate adsorbs onto the heterogeneous surface of an adsorbent (Hardiljeet et al., 2011)

The linear form of the Freundlich isotherm is as follows:

$$
\log Q_{e}=\log K_{F}+\frac{1}{n} \cdot \log C_{e}
$$

$\mathrm{K}_{\mathrm{F}}$ and $1 / \mathrm{n}$ are the parameters of the Freundlich equation.

\section{RESULTS AND DISCUSSION}

\section{Zeolite characterization}

A Faujasite zeolite with a high $\mathrm{SiO}_{2} / \mathrm{Al}_{2} \mathrm{O}_{3}$ ratio its formula: $9 \mathrm{SiO}_{2}: \mathrm{Al}_{2} \mathrm{O}_{3}: 3 \mathrm{Na}_{2} \mathrm{O}$ : $120 \mathrm{H}_{2} \mathrm{O}$, was successfully synthesized, (Holmberg et al. 2004, Wang et al. 2003). The structural characterization of zeolites is essential owing to their properties, namely, size and configuration of the cavities or channels that make up the zeolite pores. Thus, the first characterization was carried out by X-ray diffraction. The X-ray difractogram in the $2 \theta$ range, from $5^{\circ}$ to $100^{\circ}$, in figure 3 , clearly indicates the good crystallinity of the synthesized zeolite. Intense peaks located at $2 \theta$ at $21.8^{\circ}, 28.1^{\circ}$ and $33^{\circ}$. The diffraction lines are displaced towards the large angles $2 \theta$, this means that the material is rich in silica. For this zeolite, the $\mathrm{Si} / \mathrm{Al}$ ratio is around 4.5.

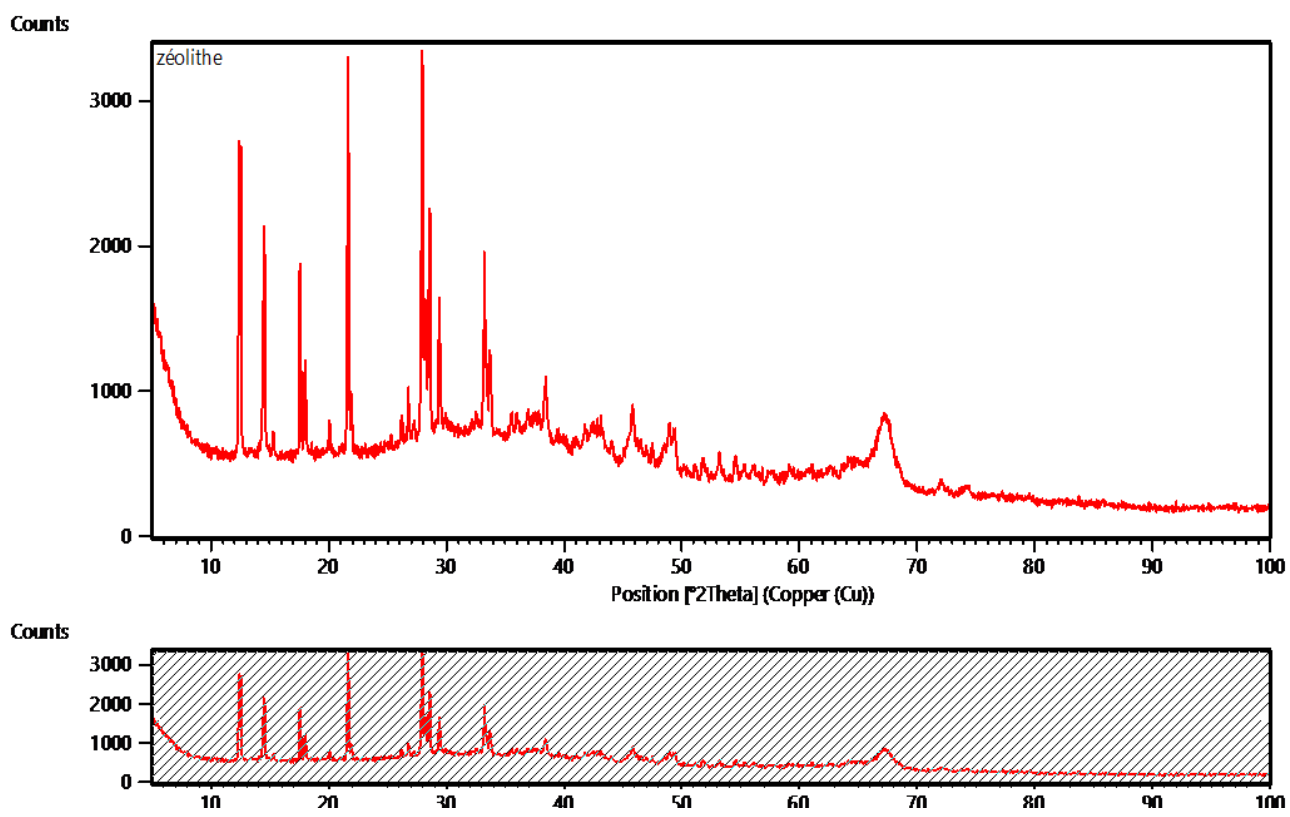

Figure 3. X-ray difractogram of synthetic Zeolite Y. 
This structure is confirmed by the SEM images (Figures 4 and 5) which clearly shows that the crystals have sharp edges and large size. On the other hand, the FTIR spectra also assert the structure of zeolite, characterized by the presence of intense bands at $477-509 \mathrm{~cm}^{-1}$ that characterize the $\mathrm{TO}_{4}$ tetrhedral site $(\mathrm{T}=\mathrm{Al}, \mathrm{T}=\mathrm{Si})$. A $609 \mathrm{~cm}^{-1}$ peak characteristic of the outside of the double ring and bands at 738-680 $\mathrm{cm}^{-1}$ and $591-427 \mathrm{~cm}^{-1}$ attributed to the symmetrical elongation and bending vibrations of TO atoms respectively (Utami et al., 2019). The 1466$1476 \mathrm{~cm}^{-1}$ bands are assigned to the internal vibrations of the T-O-T tetrahedron and finally a $1638 \mathrm{~cm}^{-1}$ band characterizing the $\mathrm{O}-\mathrm{H}$ bond of the water.

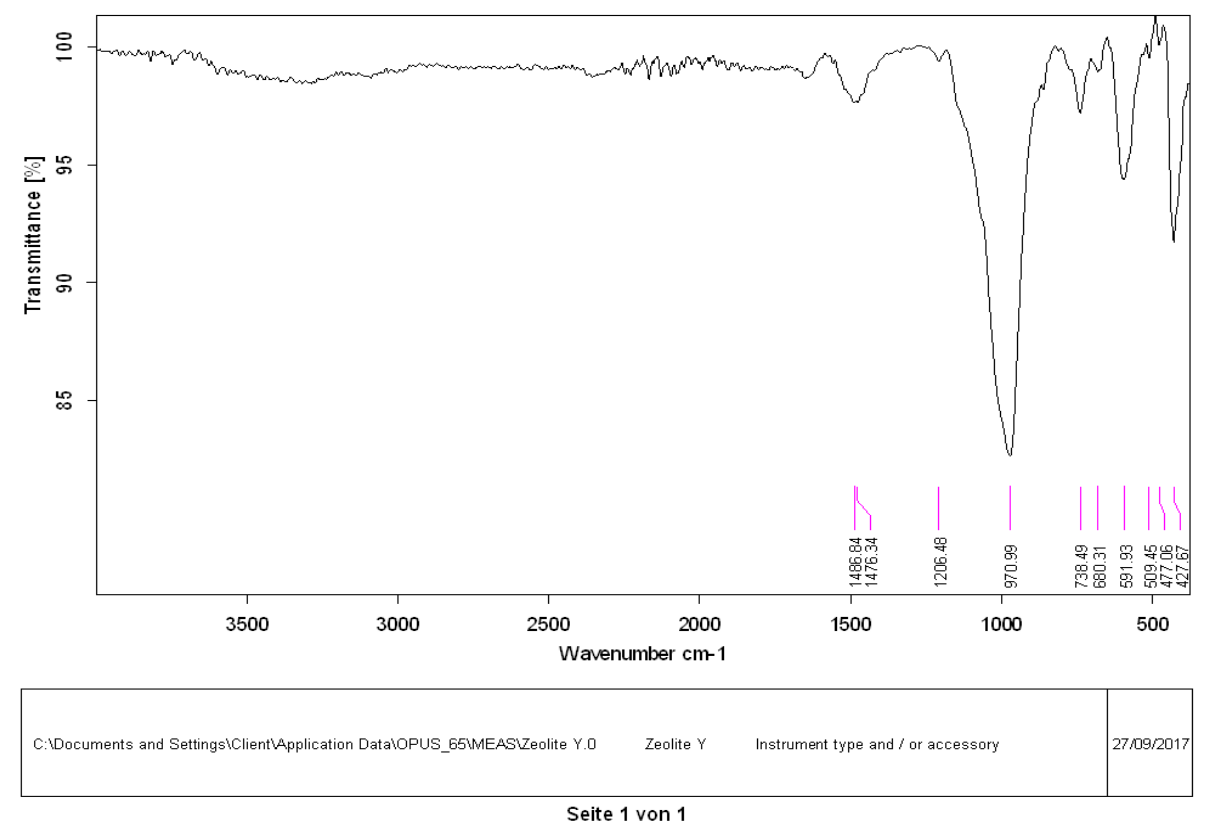

Figure 4. FTIR analysis of synthetic Zeolite Y.

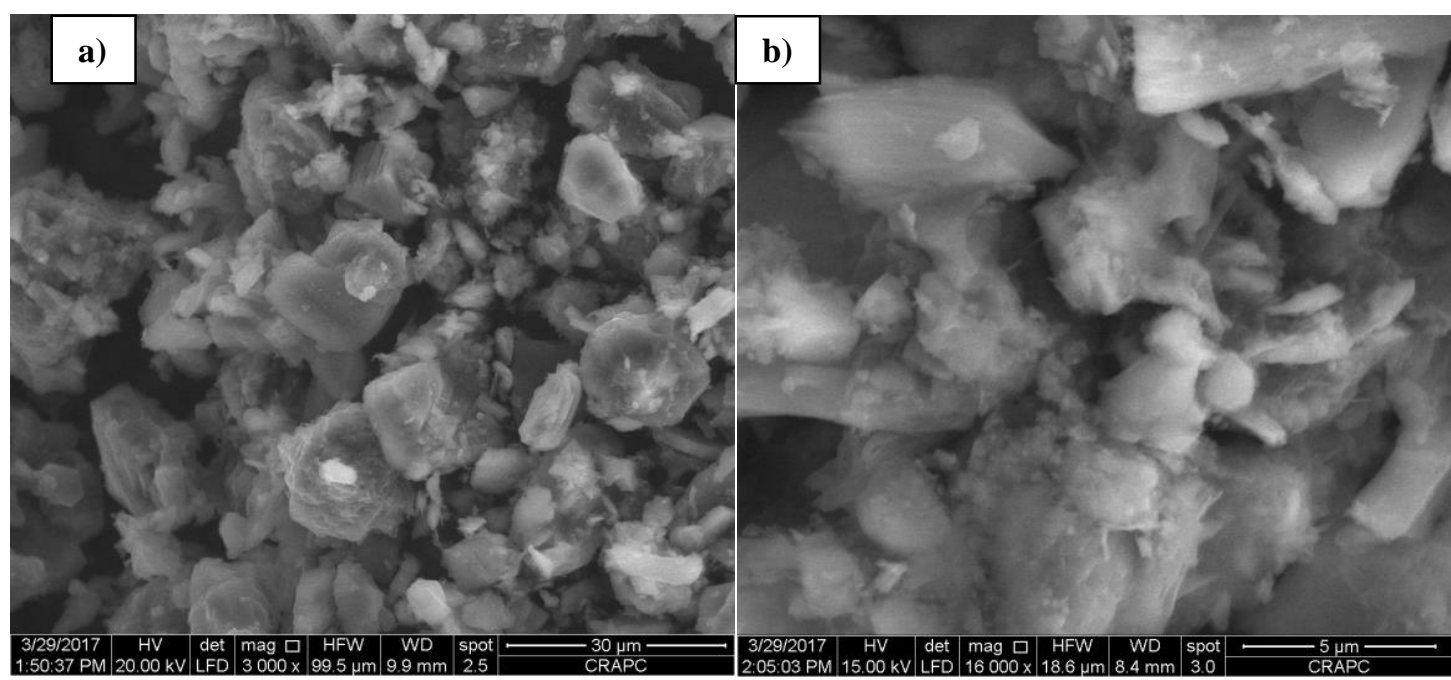

Figure 5. SEM analysis of synthetic zeolite $\mathrm{Y}$ (a: image at 3000X magnification, b: image at $16000 \mathrm{X}$ magnification).

\section{Removal of heavy metals}

The below Table 2 summarizes the results of the treatment of the industrial effluent of the Bounoura industrial zone with zeolite Y. The first and second columns contain respectively 
the values of the initial $C_{i}$ and final concentrations $C_{f}$ of heavy metals before and after treatment. The third column shows the heavy metals removal rates by the zeolite. The last column includes the tolerable concentrations of heavy metals $\mathrm{C}_{\mathrm{Max}}$ required by the Algerian standards, in accordance with Executive Decree 09-209 of 11/06/2009, fixing the terms and conditions for granting the authorization to waste water discharge other than in a public network sanitation or in a station of purification (JORA, 2009).

Table 2. Heavy metals removal rates from industrial effluent, by Na-Y zeolite.

\begin{tabular}{|c|c|c|c|c|}
\hline Metal & $\mathrm{C}_{\mathrm{i}}(\mathrm{mg} / \mathrm{L})$ & $\mathrm{C}_{\mathrm{f}(\mathrm{mg} / \mathrm{L})}$ & Rate \% & $\mathrm{C}_{\operatorname{Max}}(\mathrm{mg} / \mathrm{L})$ \\
\hline $\mathrm{Fe}^{2+}$ & 4.543 & 1.157 & 74.541 & 1.00 \\
\hline $\mathrm{Cu}^{2+}$ & 4.377 & 3.533 & 19.269 & 1.00 \\
\hline $\mathbf{Z n}^{2+}$ & 0.917 & 0.643 & 29.818 & 2.00 \\
\hline $\mathrm{Mn}^{2+}$ & 11.733 & 2.767 & 76.420 & - \\
\hline $\mathrm{Ni}^{2+}$ & 21.520 & 13.150 & 38.894 & 2.00 \\
\hline $\mathbf{S n}^{2+}$ & 0.533 & 0.130 & 75.625 & 0.10 \\
\hline $\mathrm{Mg}^{2+}$ & 239.067 & 154.707 & 35.287 & 300.00 \\
\hline $\mathbf{P b}^{2+}$ & 0.573 & 0.370 & 35.465 & 0.50 \\
\hline $\mathrm{Cd}^{2+}$ & 0.397 & 0.054 & 86.471 & 0.10 \\
\hline $\mathrm{Cr}^{2+}$ & 0.782 & 0.214 & 72.665 & 2.00 \\
\hline $\mathrm{Hg}^{2+}$ & 0.000 & 0.000 & - & 0.01 \\
\hline $\mathbf{A s}^{3+}$ & 0.000 & 0.000 & - & 0.01 \\
\hline Total & 284.442 & 176.724 & 37.870 & - \\
\hline
\end{tabular}

The results show that raw wastewater from the studies industrial site is overloaded with metals which causes numerous risks on the organism and the environment.

Most metal concentrations exceed the limits tolerated by the Algerian standards for industrial water discharges (JORA, 2009).

It highlights a very high concentration for iron $(5.9 \mathrm{mg} / \mathrm{l})$, nickel $(4.26 \mathrm{mg} / \mathrm{l})$ and tin $(0.5$ $\mathrm{mg} / \mathrm{l})$. Concentrations are just within the required limits for magnesium $(228.8 \mathrm{mg} / \mathrm{l})$ and lead $(0.52 \mathrm{mg} / \mathrm{l})$ and are tolerable for the remaining metals. Mercury and arsenic are practically absent in the effluent. Their contents have been detected in traces.

The total initial concentration of heavy metals, analyzed in the effluent, is of the order of $284.4 \mathrm{mg} / \mathrm{L}$, after treatment and agitation of the effluent with the zeolite, the total final concentration is reduced to $176.7 \mathrm{mg} / \mathrm{L}$, with a removal rate of the order of $38 \%$.

The zeolite is able to eliminate nearly $40 \%$ of the ten heavy metals analyzed. This result is satisfactory since the effluent contains, in addition to metals, other pollutants and organic materials, such as: nitrates, nitrites and others, for example, COD, BOD5 and suspended matter have been reduced to the respective percentages: $55.4,64.07$ and $71.32 \%$.

The adsorption rates by zeolite $\mathrm{Y}$ in the effluent studied are low compared to those found by Parag et al., (2010) in the treatment of an effluent from a metallurgical industry, with zeolite A, iron was eliminated with $99.23 \%$, copper $97.37 \%$ and zinc with $94.68 \%$. But our results are clearly better than those found by Sabry M. S. et al. (Sabry et al., 2012) in their study of the 
elimination of some heavy metals by a natural zeolite (clinoptilolite), in which the elimination rates of copper, cadmium and nickel were valued at $47 \%, 22 \%$ and $29 \%$ respectively.

In this study, the results demonstrate a decreasing order of the removal rates of metals as follows: $\mathrm{Cd}>\mathrm{Mn}>\mathrm{Sn}>\mathrm{Fe}>\mathrm{Cr}>\mathrm{Ni}>\mathrm{Pb}>\mathrm{Mg}>\mathrm{Zn}>\mathrm{Cu}$. Cadmium is the most adsorbed metal with a rate of $86.47 \%$ and copper takes the last position with a rate of removal of $19.27 \%$.

Lead is better adsorbed than zinc and copper by zeolite, this is probably due to the adsorption selectivity of zeolite vis-a-vis these metals. This is confirmed by the results found by Kesraouiouki et al., (1994) and Caputo and Pepe (Caputo and Pepe, 2007) in their studies of the removal of heavy metals by zeolites.

\section{Kinetic study}

Parameters of linear forms of kinetic models for pseudo-first-order and pseudo-secondorder are given in figures 6 and 7 below, and summarized in table 3. The correlation coefficients associated to the linear fits was used to evaluate the best model to describe the metal ions adsorption data. Results demonstrate that the pseudo-second-order model is the most appropriate to represent cadmium removal kinetics by synthetized zeolite.

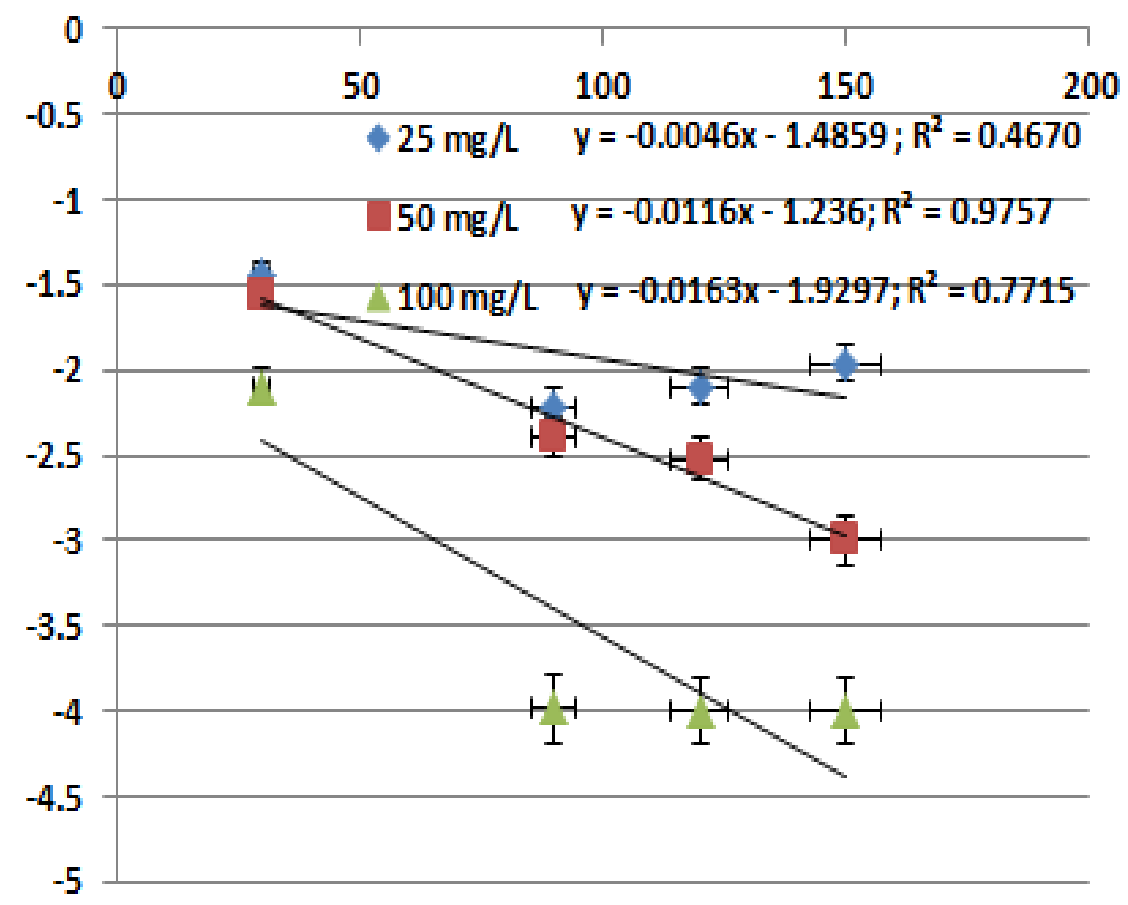

Figure 6. 1st order kinetic model. 


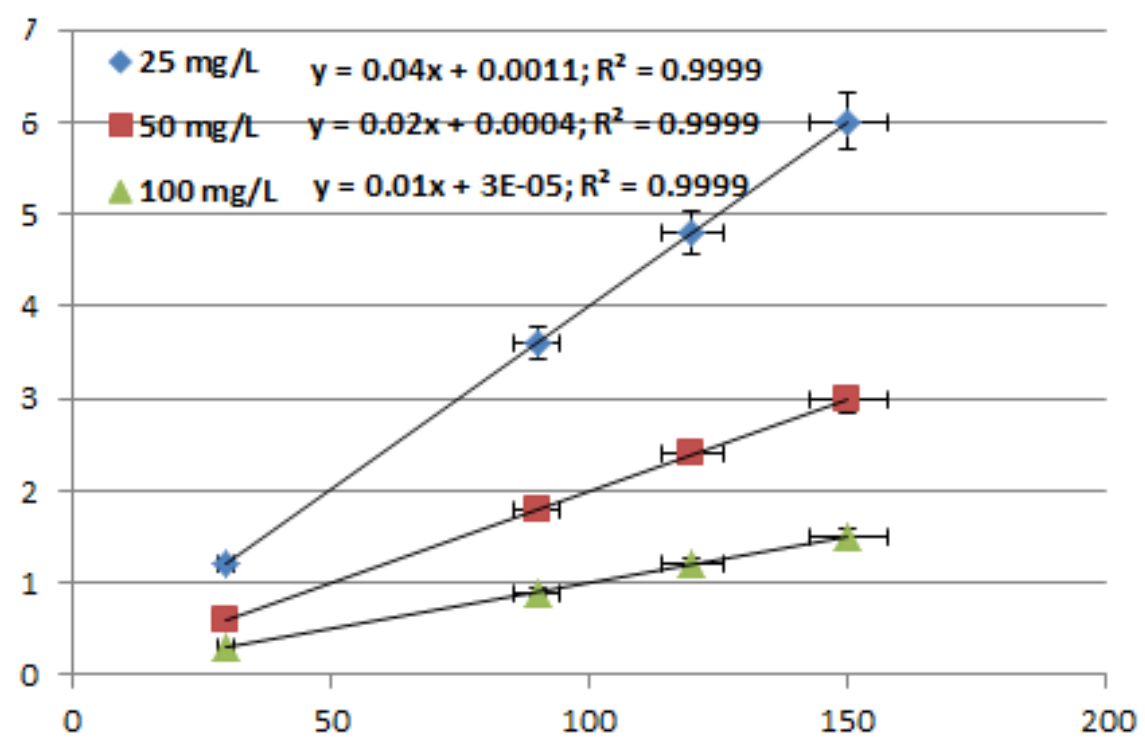

Figure 7. 2nd order kinetic model.

Table 3. Parameters of 1st and 2nd order kinetic models.

\begin{tabular}{|c|c|c|c|c|c|c|}
\hline \multirow[b]{2}{*}{$\mathrm{C}_{0}(\mathrm{mg} / \mathrm{L})$} & \multicolumn{3}{|c|}{ pseudo-first-order } & \multicolumn{3}{|c|}{ pseudo-second-order } \\
\hline & $\mathrm{K}_{1}\left(\mathrm{~min}^{-1}\right)$ & $Q_{e}\left(m_{g \cdot g^{-1}}\right)$ & $\overline{\mathbf{R}^{2}}$ & $\mathrm{~K}_{2}\left(\mathrm{~g} \cdot \mathrm{mg}^{-1} \cdot \mathrm{min}^{-1}\right)$ & $Q_{\mathrm{e}}\left(\mathrm{mg} \cdot \mathrm{g}^{-1}\right)$ & $\mathbf{R}^{2}$ \\
\hline 25 & 0.004 & 0.227 & 0.467 & 1.455 & 25 & 0.999 \\
\hline 50 & 1.236 & 0.989 & 0.975 & 1.000 & 50 & 0.999 \\
\hline 100 & 0.016 & 0.145 & 0.771 & 3.333 & 100 & 0.999 \\
\hline
\end{tabular}

\section{Adsorption isotherms}

Adsorption isotherms provide some information on how an adsorption system proceeds, and indicate how molecules of adsorbate interact with adsorbent. Figures 8 and 9 below, represent the Langmuir and Freundlich isotherms for the adsorption of cadmium by the zeolite, the parameters of their linear equations are summarized in Table 4 below.

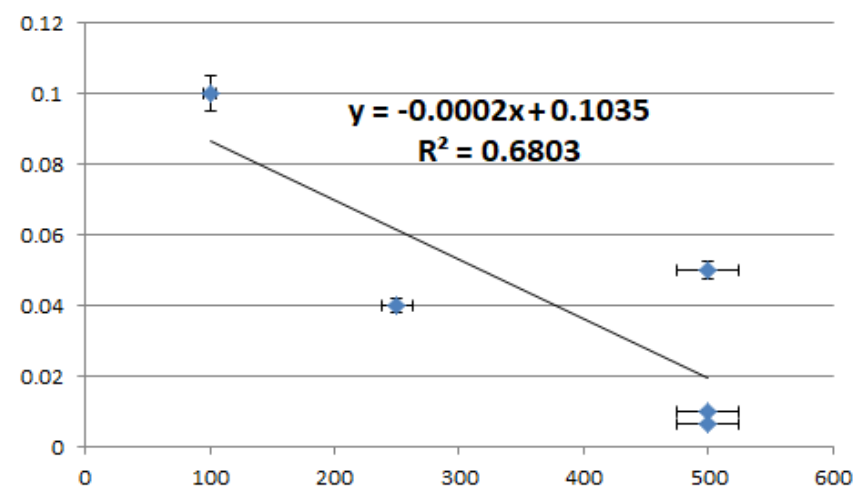

Figure 8. Langmuir adsorption isotherm.

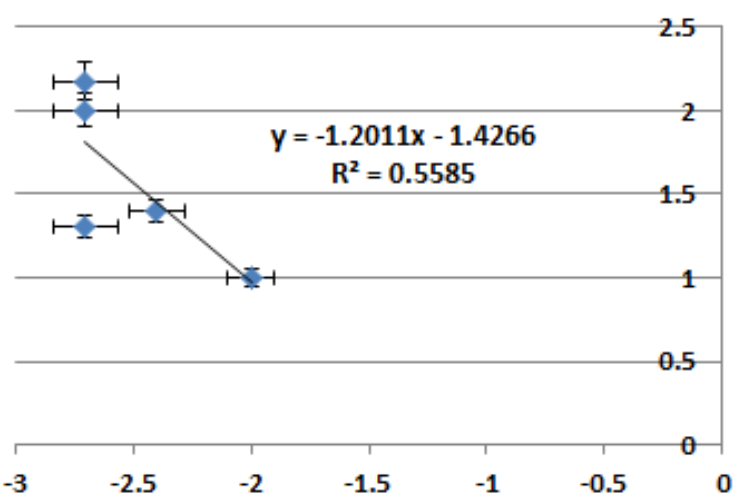

Figure 9. Freundlich adsorption isotherm. 
Table 4. Parameters of the models for adsorption isotherms.

\begin{tabular}{|l|l|l|l|l|l|}
\hline \multicolumn{2}{|l|}{ Langmuir model } & \multicolumn{3}{l|}{ Freundlich model } \\
\hline $\mathrm{Q}_{\mathrm{m}}\left(\mathrm{mg} \cdot \mathrm{g}^{-1}\right)$ & $\mathrm{K}_{\mathrm{L}}\left(\mathrm{L} \cdot \mathrm{g}^{-1}\right)$ & $\mathrm{R}^{2}$ & $1 / \mathrm{n}$ & $\mathrm{K}_{\mathrm{F}}$ & $\mathrm{R}^{2}$ \\
\hline 96.618 & 0.517 & 0.680 & -1.201 & 0.240 & 0.558 \\
\hline
\end{tabular}

Based on R-squared values, Langmuir isotherm model signifies the best correspondence with the experimental data. The maximum adsorption capacity $Q_{m}$ is $96.62 \mathrm{mg} / \mathrm{g}$. This isotherm is associated to a monolayer adsorption involving homogeneous interactions with the solute.

The adsorption of cadmium is weakly represented by the Freundlich isotherm with an $\mathrm{R}$-squared value of the order of 0.558 . This isotherm defines the surface heterogeneity and the exponential distribution of active sites and their energies. The parameters of the linear model of this isotherm for $\mathrm{K}_{\mathrm{F}}$ and $1 / \mathrm{n}$ are 0.240 and -1.201 , respectively.

\section{CONCLUSION}

In this study, due to the use of hydrothermal method, zeolite Na-Y was successfully synthesized. Many techniques were used to characterize the zeolite and to confirm its structure, such us: X-ray diffraction analysis (XRD), Fourier transform infrared spectroscopy (FTIR) and scanning electron microscopy (SEM).

In order to test the effectiveness of the zeolite in reducing the concentration of pollutants contained in an industrial effluent, samples of wastewater were taken from an effluent from a very important industrial area of southeastern Algeria (Bounoura Industrial zone, Wilaya of Ghardaïa). The analysis of ten heavy metals in the effluent shows that it contains eccessive heavy metal rates, whose concentrations exceed the Algerian standards required.

Tests for removal of these metals by agitation in the synthesized zeolite show that it is an effective adsorbent capable of reducing up to $37.87 \%$ of the heavy metals contained in the effluent. The reduction is in decreasing order of: $\mathrm{Cd}>\mathrm{Mn}>\mathrm{Sn}>\mathrm{Fe}>\mathrm{Cr}>\mathrm{Ni}>\mathrm{Pb}>\mathrm{Mg}>$ $\mathrm{Zn}>\mathrm{Cu}$. Cadmium is the most adsorbed metal with a rate of $86.47 \%$ and copper takes the last position with a rate of removal of $19.27 \%$.

Cadmium removal kinetics by synthesized zeolite is successfully modeled by the pseudo-second order rate equation; nonetheless, the Langmuir isotherms fit well the adsorption of this metal.

The study also shows the effectiveness of synthetic zeolite and its great ability to reduce pollutant levels of industrial effluents that can harm the environment and threaten the life of living beings.

\section{ACKNOWLEDGEMENT}

We sincerely thank and express our gratitude to the staff members of the laboratory of mathematics and applied sciences of Ghardaïa University (Algeria) who rendered their help during the period of this project work. 


\section{REFERENCES}

Aderemi, B. O. (2004). Preliminary Studies on Synthesis of Zeolites from Local Clay. Nigerian Journal of Scientific Research, 4(2), 7-12.

American Public Health Association. (1998). Standard methodsfor the examination of water and wastewater, 20th edn. APHA, Washington, DC.

Arshid, B., Lateef, A. M., Sozia, A., Taniya, M., Mudasir, A. B., Dar, G. N., \& Altaf, H. P. (2019). Removal of heavy metal ions from aqueous system by ion-exchangeand biosorption methods. Environmental Chemistry Letters, 17, 729-754.

Asad, S. A., Farooq, M. A., fzal, A., \& West, H. (2019). Integrated phytobial heavy metal remediation strategies for a sustainable clean environment - A review. Chemosphere, 217, 925-941.

Benoudj, A., Touaibia, B., \& Hubert, P. (2014). Floods in the Mzab valley (South Algeria): Genesis and prediction, Le Journal de l'Eau de de l'Environnement, 25, 20-34.

Brad, H. B. (2005). Sources and origins of heavy metals. Interface Science and Technology, 6, $1-27$.

Bhuiyan, M. A., Suruvi, N. I., Dampare, S. B., Islam, M. A., Quraishi, S. B., Ganyaglo, S., \& Suzuki, S. (2011). Investigation of the possible sources of heavy metal contamination in lagoon and canal water in the tannery industrial area in Dhaka, Bangladesh. Environ Monit Assess. 175, 633-649.

Caputo, D., \& Pepe, F. (2007). Experiments and data processing of ion exchange equilibria involving Italian natural zeolites - a review. Microporous Mesoporous Mater, 105, 222-231.

Christensen, T. H., Bjerg, P. L., \& Kjeldsen, P. (2000). Natural attenuation: a feasible approach to remediation of ground water pollution at landfills?. Ground Water Monit. Rem., 20, 69-77.

Dietler, D., Babu, M., Cissé, G., Halage, A. A., Malambala, E., \& Fuhrimann, S. (2019). Daily variation of heavy metal contamination and its potential sources along the major urban wastewater channel in Kampala, Uganda. Environ Monit Assess., 191(2), 52. doi: 10.1007/s10661-018-7175-4.

Elwakeel, K. Z., El-Bindary, A. A., \& Kouta, E. Y. (2017). Retention of copper, cadmium and lead from water by Na-Y-Zeolite confined in methyl methacrylate shell. Journal of Environmental Chemical Engineering, 5, 36983710 .

Google (n,d). (Google Map of Ghardaia, Algeria). Retrieved July 22, 2019 from https://goo.gl/maps/7Y5kDNd6F9cSZjs28

Hardiljeet, K. B., Joseph, M., \& O'Carroll, M. D. (2011). Kinetics and thermodynamics of cadmium ion removal by adsorption onto nanozerovalent iron particles. Journal of Hazardous Materials, 186, 458-465.

Holmberg, B. A., Wang, H., Norbeck, J. M., \& Yan, Y. (2003). Control-ling size and yield of zeolite Y nanocrystals using tetramethylam-monium bromide. Microporous and Mesoporous Materials, 59(1), 13-28.

Holmberg, B. A., Wang, H., \& Yan, Y. (2004). High silica zeolite Y nanocrystals by dealuminationand direct synthesis. Microporous and Mesoporous Materials, 74, 189198.

Hou, D., O'Connor, D., Nathanail, P., Tian, L., \& Ma, Y. (2017). GIS and multivariate statistical analysis for regional scale assessment of heavy metal soil contamination: a critical review. Environ. Pollut., 231, 1188-1200. 
International Union of Pure and Applied Chemistry. (2002). Heavy Metals - A Meaningless term?. Pure Appl. Chem., 74(5), 793-807.

Jarup, L. (2003). Hazards of heavy metal contamination, Br. Med. Bull., 68(1), 167-182.

JORA. (2009). Maximum limit values for the content of substances harmful to non-domestic wastewater in thewhen they are discharged into a networkpublic sanitation or in a stationpurification, DE $\mathrm{n}^{\circ}$ 09-209 fixing theterms and conditions for granting the authorization towaste water discharge other thanin a public networksanitation or in a stationof purification.

Kesraouiouki, S., Cheeseman, C. R., \& Perry, R. (1994). Natural zeolite utilization in pollution control - a review of applications to metaleffluents. J. Chem. Techno.l Biotechnol., 59, 221-231.

Majid, M. S. (2015). Crystallization Behavior of Synthesized Zeolite-A from Iraqi Kaolin. International Journal of Engineering and Technology (IJET), 5(12), 617-622.

Medejerab, A. (2009). Les inondations catastrophiques du mois d'octobre 2008 à Ghardaïa. GeographiaTechnica, (Special), 311-316.

Meenakshi, M. R. C. (2006). Fluoride in drinking water and its removal. J. Hazard Mater, 137, 456-463.

Merrikhpour, H., \& Jalali, M. (2013). Comparative and competitive adsorption of cadmium, copper nickel, and lead ions by Iranian natural zeolite. Clean Techn Environ Policy, 15, 303-316.

Mohd, I., Adil, S., Lata, V., Jiwan, S., \& Janardhan, R. K. (2019). Adsorptive Removal of Fluoride from Aqueous Solution by Biogenic Iron Permeated Activated Carbon Derived from Sweet Lime Waste, ActaChim. Slov. 66,123-136.

Nahar, K., Chowdhury, M. A. K., Chowdhury, M. A. H., Rahman, A., \& Mohiuddin, K. M. (2018). Heavy metals in handloom-dyeing effluents and their biosorption by agricultural byproducts. Environ SciPollut Res Int., 25(8), 7954-7967.

Nik, A., Nik, M., \& Alias, M. Y. (2007). Removal of Cr (III) from aqueous solution using Zeolite Na-Y Prepared from Rice husks ash. The Malaysian Journal of analytical science, 11(1), 76-83.

Parag, S., Vikal, G., \& Ruchi, K. (2010). Synthesis of Zeolite from Fly Ash and Removal of Heavy Metal Ions from Newly Synthesized Zeolite. E-Journal of Chemistry, 7(4), 12001205.

Sabry, M. S., Derbalah, A. S., \& Farahat, S. M. (2012). Removal of Heavy Metals from Aqueous Solution by Zeolite in Competitive Sorption System. International Journal of Environmental Science and Development, 3(4), 362-367.

Shamsan, S. O., Gaikwada, D. K., Sayyed, M. I., AL-Rashdi, K., \& Pawar, P. P. (2018). Heavy metal ions removal from waste water bythe natural zeolites. Materials Today: Proceedings, 5, 17930-17934.

Utami, A. R., Sugiarti, S., \& Sugita, P. (2019). Synthesis of NaP1 and Faujasite Zeolite from natural zeolite of Ende-NTT as lead (Pb(II)) adsorbent. Rasayan J. Chem., 12(2), 650658.

Wang, H., Holmberg, B. A., \& Yan, Y. (2003). Synthesis of Template-Free Zeolite Nanocrystals by Using in Situ Thermoreversible Polymer Hydrogels. J. Am. Chem. Soc., 125, 99289929.

Wang, J., \& Chen, C. (2010). Research advances in heavy metal removal by biosorption. Acta. Sci. Circumstantiae, 30, 673-701.

Yanyan, G., Dongye, Z., \& Qilin, W. (2018). An overview of field-scale studies on remediation of soil contaminated with heavy metals and metalloids: Technical progress over the last decade. Water Research, 147, 440-460. 
Yadav, V. B., Gadi, R., \& Kalra, S. (2019). Clay based nanocomposites for removal of heavy metals from water: A review. J. Environ. Manage., 232, 803-817.

Ying, H. L., Wang, W., Wang, T. L., Zhenli, H., \& Xiaoe, Y. (2019). Current status of agricultural soil pollution by heavy metals in China: A meta-analysis. Science of the Total Environment, 651(2), 3034-3042. 